\title{
P388: Evaluation of the outsourcing of public hospital cleaning / case of university hospital Yalgado Ouedraogo
}

\author{
J Zoungrana ${ }^{1 *}$, A Traoré $^{2}$ \\ From 2nd International Conference on Prevention and Infection Control (ICPIC 2013) \\ Geneva, Switzerland. 25-28 June 2013
}

\section{Introduction}

Lack of tangible evidence proving the effectiveness and efficiency of the outsourcing of cleaning compared to self cleaning. Need to evaluate the outsourcing of cleaning.

\section{Objectives}

Evaluate cleaning subcontracting of CHUYO. The specific objectives were: 1 . To assess the cleaning process at CHUYO; 2. To assess the effectiveness of cleaning in comparison to standards; 3 . To discuss the factors explaining any gaps identified.

\section{Methods}

Descriptive cross-sectional survey conducted from 04 to 10 July 2011. Collection of information from patients and healthcare personnel. We used a questionnaire survey addressing the following items: work organization, human resources, cleaning procedures, material resources. Surface sampling 15 minutes after cleaning operations were conducted.

\section{Results}

- 95\% of patients feel that they were satisfied with the cleaning done by a private company;

- $75 \%$ of patients feel that they are not disturbed by the passage cleaning crews;

- $89 \%$ of patients report that their products used do not cause any discomfort;

- 77\% of professionals are satisfied with the quality of cleaning, - There were dissatisfaction in 3 points: transit schedules not suitable for some patients, lack of staff, staff discourteous.

- 93\% of study participants prefer subcontracted cleaning rather than self cleaning.

\section{Conclusion}

Strengthening the achievements of subcontracting (apparent cleanliness and satisfaction of users and health professionals). Ensure training of cleaning staff, establish mechanisms for monitoring bacteriological quality surfaces and disinfectants.

\section{Disclosure of interest}

None declared.

\section{Author details}

${ }^{1}$ RIPAQS, Burkinabe Association for Improving Patient Safety, Burkina Faso. ${ }^{2}$ Hospital Universitary Centre Yalgado Ouedraogo, Ministry of Health,

Ouagadougou, Burkina Faso.

Published: 20 June 2013
doi:10.1186/2047-2994-2-S1-P388

Cite this article as: Zoungrana and Traoré: P388: Evaluation of the outsourcing of public hospital cleaning / case of university hospital Yalgado Ouedraogo. Antimicrobial Resistance and Infection Control 20132 (Suppl 1):P388. 